\title{
NONO/TFE3 Fusion Gene
}

National Cancer Institute

\section{Source}

National Cancer Institute. NONO/TFE3 Fusion Gene. NCI Thesaurus. Code C101061.

A fusion gene that results from a chromosomal inversion inv $(X)(p 11.2 ; q 12)$ which fuses exon 9 of the NONO gene with exon 6 of the TFE3 gene. This rearrang ement is associated with one case of renal cell carcinoma. 